\title{
Seroprevalence and hematological abnormalities associated with Ehrlichia canis in dogs referred to a veterinary teaching hospital in central-western Brazil
}

\author{
Warley Vieira de Freitas Paula ${ }^{1}$ (D) Ísis Indaiara Gonçalves Granjeiro Taques ${ }^{2}$ (D) \\ Vanessa Carvalho Miranda ${ }^{1}$ (D) Ana Laura Gonçalves Barreto ${ }^{1}$ (D) \\ Luiza Gabriella Ferreira de Paula ${ }^{1}$ (D) Danieli Brolo Martins ${ }^{3}$ (D) Adilson Donizeti Damasceno DiD $^{3}$ \\ Sebastián Muñoz-Leal ${ }^{4}$ Anaiá da Paixão Sevá ${ }^{(1)}$ Filipe Dantas-Torres $^{6}$ (1) \\ Daniel Moura de Aguiar $^{2}$ (i) Felipe da Silva Krawczak ${ }^{*}$ (D)
}

${ }^{1}$ Departamento de Medicina Veterinária, Setor de Medicina Veterinária Preventiva, Escola de Veterinária e Zootecnia, Universidade Federal de Goiás (UFG), 74690-900, Goiânia, GO, Brasil. E-mail: felipekvet@ufg.br. "Corresponding author.

${ }^{2}$ Laboratório de Virologia e Rickettsiose, Faculdade de Medicina Veterinária, Universidade Federal de Mato Grosso (UFMT), Cuiabá, MT, Brasil.

${ }^{3}$ Departamento de Medicina Veterinária, Setor de Clínica e Cirurgia, Escola de Veterinária e Zootecnia, Universidade Federal de Goiás (UFG), Goiânia, GO, Brasil.

${ }^{4}$ Departamento de Patología y Medicina Preventiva, Facultad de Ciencias Veterinarias, Universidad de Concepción, Chillán, Nuble, Chile.

${ }^{5}$ Departamento de Ciências Agrárias e Ambientais, Universidade Estadual de Santa Cruz (UESC), Ilhéus, BA, Brasil.

${ }^{6}$ Departamento de Imunologia, Instituto Aggeu Magalhães (IAM), Fundação Oswaldo Cruz (Fiocruz), Recife, PE, Brasil.

ABSTRACT: Ticks are significant parasites of dogs in the tropics, where tick-borne pathogens are highly prevalent, especially in areas where tick control measures are frequently neglected. This study investigated the seroprevalence and hematological abnormalities associated with Ehrlichia canis in dogs referred to a veterinary teaching hospital in Central-western Brazil. Out of 264 dogs tested for anti-Ehrlichia canis antibodies by an indirect immunofluorescence assay (IFA), 59.1\% (156/264) were positive. Seropositivity was significantly associated to anemia and thrombocytopenia, alone or in combination, and to leukopenia. Conversely, there were no differences in terms of seroprevalence according to sex, breed and age. This study demonstrated that dogs referred to a veterinary teaching hospital in Central-western Brazil are highly exposed to E. canis and that seropositive dogs are more likely to present hematological abnormalities, particularly anemia, thrombocytopenia and leukopenia. To our knowledge, this is the first study on detection of anti-E. canis antibodies by means of IFA among dogs in the state of Goiás. These findings highlighted the need for increasing awareness among dog owners regarding tick control measures in Central-western Brazil, ultimately to reduce the risk of exposure to E. canis and other tick-borne pathogens.

Key words: ehrlichiosis, epidemiology, indirect immunofluorescence assay, tick-borne diseases, clinical pathology, Goiás state

Soroprevalência e alterações hematológicas associadas com Ehrlichia canis em cães encaminhados a um hospital veterinário-escola no centro-oeste do Brasil

RESUMO: Carrapatos são importantes parasitos de cães nos trópicos, onde patógenos transmitidos por carrapatos são altamente prevalentes, especialmente em áreas onde as medidas de controle de carrapatos são frequentemente negligenciadas. O estudo investigou a soroprevalência $e$ as anormalidades hematológicas associadas à Ehrlichia canis em cães encaminhados para um hospital veterinário-escola no Centro-oeste do Brasil. Dos 264 cães testados para anticorpos anti-Ehrlichia canis por meio da reação de imunofluorescência indireta (RIFI), 59.1\% (156/264) foram positivos. A soropositividade foi associada significativamente à anemia e trombocitopenia, isoladamente ou em combinação, e à leucopenia. Por outro lado, não houve diferenças quanto à soroprevalência segundo sexo, raça e idade. Este estudo demonstrou que cães encaminhados a um hospital veterinário-escola na região Centro-oeste do Brasil são altamente expostos à E. canis, e que cães soropositivos têm maior probabilidade de apresentar alterações hematológicas, principalmente anemia, trombocitopenia e leucopenia. Para o nosso conhecimento, este é o primeiro estudo sobre a detecção de anticorpos anti-E. canis por meio da RIFI em cães do estado de Goiás. Essas descobertas destacam a necessidade de aumentar a conscientização entre os proprietários de cães em relação às medidas de controle do carrapato no Centro-oeste do Brasil, em última análise, para reduzir o risco de exposição ao E. canis e outros patógenos transmitidos por carrapatos. Palavras-chave: erliquiose, epidemiologia, reação de imunofluorescência indireta, doença transmitida por carrapato, patologia clínica, estado de Goiás.

\section{INTRODUCTION}

Ticks are significant parasites of dogs in the tropics, where tick-borne pathogens are highly prevalent, especially in regions where tick control measures are frequently neglected (MAGGI \& KRÄMER, 2019; DANTAS-TORRES et al., 2020). For instance, Ehrlichia canis is a tick-borne pathogen that infects predominantly cells of the mononuclear phagocyte system of canids (DUMLER et al., 2001). 
This pathogen is primarily transmitted by brown dog ticks (Rhipicephalus sanguineus sensu lato) and is the cause of canine monocytic ehrlichiosis (CME), a disease that affects dogs worldwide, but especially in tropical and subtropical regions (SAINZ et al., 2015). Indeed, CME is a multisystemic disease with variable clinical manifestations, ranging from subclinical to life-threatening disease (HARRUS \& WANER, 2011; SAINZ et al., 2015; MAGGI \& KRÄMER, 2019). Its severity depends on various factors, including the pathogen strain, immune response of the dog and presence of concomitant infections (SAINZ et al., 2015). Sick dogs may display unspecific clinical signs and hematological abnormalities, such as fever, weakness, lethargy, anorexia, lymphadenomegaly, splenomegaly, hepatomegaly, weight loss, pale mucous membranes, epistaxis, petechiae, ecchymoses, anemia and thrombocytopenia (SAINZ et al., 2015).

While E. canis presents a worldwide distribution, it is more prevalent in tropical and subtropical regions as compared with temperate regions. This is evident in Latin America, where several hotspots of $E$. canis infection have been detected (MAGGI \& KRÄMER, 2019; BADER et al. 2020; DANTAS-TORRES et al., 2020). For instance, low seroprevalences $(<10 \%)$ have been reported in countries located in the extreme south of Latin America, such as Argentina, Uruguay and Chile (MAGGI \& KRÄMER, 2019). Conversely, moderate to high seroprevalences have been detected in tropical regions of Latin America (MAGGI \& KRÄMER, 2019). This difference in terms of seroprevalence of $E$. canis is also evident in Brazil, a country with continental dimensions. In this country, seroprevalences ranging from $0.7 \%$ to $92.3 \%$ have been reported, with the lowest seroprevalences detected in the southern region and the highest from the southeastern region towards the north of the country (VIEIRA et al., 2011). The lower prevalence of CME in the southern Brazil has been be related to the geographical distribution of different lineages of $R$. sanguineus s.l. ticks (MORAES-FILHO et al., 2011). Nonetheless, differences in terms of prevalence may also be related to other factors, including dog owners' attitude towards the control of ticks. Indeed; although, there is a vast repertoire of veterinary products against ticks on dogs in Brazil, the use of such products as preventive tools varies widely from region to region (FIGUEREDO et al., 2017), thus facilitating the transmission of tick-borne pathogens such as E. canis (DANTAS-TORRES \& OTRANTO, 2014).
Most studies investigating the seroprevalence of E. canis in dogs in Brazil have been conducted in the southeastern region of the country (VIEIRA et al., 2011). For instance, limited information is available for the Central-west region of Brazil. In the same way, information on the seroprevalence of E. canis in hospital population in Brazil is fragmentary. Considering that the tropical lineage of $R$. sanguineus s.l. is present in Centralwestern Brazil, we hypothesized that even dogs with access to healthcare services are highly exposed to E. canis in this region. To investigate this hypothesis, we evaluated the seroprevalence and hematological abnormalities associated with E. canis in dogs referred to a veterinary teaching hospital in Centralwestern Brazil.

\section{MATERIALS AND METHODS}

\section{Study population}

The study population enrolled in this cross-sectional study included 264 dogs referred to the Veterinary Teaching Hospital of the School of Veterinary Medicine and Animal Science of the Federal University of Goiás (UFG), between November 2017 and April 2018. The hospital is located in Goiânia city $\left(16^{\circ} 40^{\prime} \mathrm{S}, 49^{\circ} 15^{\prime} \mathrm{W}\right)$, Goiás State, but dogs came from several municipalities: Goiânia $(\mathrm{n}=232)$, Aparecida de Goiânia $(\mathrm{n}=12)$, Trindade $(n=5)$, Senador Canedo $(n=4)$, Santo Antônio de Goiás $(\mathrm{n}=3)$, Caturaí $(\mathrm{n}=1)$, Goianira ( $\mathrm{n}$ $=1)$, Inhumas $(n=1)$, Itaguari $(n=1)$, Itaguaru $(n=1)$, Mossâmedes ( $\mathrm{n}=1)$, Rio Quente $(\mathrm{n}=1)$ and Silvânia $(n=1)$ (Figure 1). Dogs were referred to the hospital for various routine procedures, not necessarily due to suspicion of CME or other tick-borne diseases.

Out of 264 dogs sampled, $57.6 \%(152 / 264)$ were females and $42.4 \%(112 / 264)$ males. With regard to breed, $64.4 \%(170 / 264)$ were purebred and $35.6 \%$ (94/264) mongrels. Finally, 41.3\% (109/264) of the dogs were $6-10$ years, $28.4 \%(75 / 264) 1-5$ years, $20.1 \%(53 / 264)>10$ years, and $7.2 \%(19 / 264)<1$ year old; for eight dogs, age information was missing.

\section{Hematological evaluation}

Blood samples $(3 \mathrm{~mL})$ from dogs were withdrawn from the cephalic or jugular veins into Vacutainer $^{\circledR}$ tubes containing EDTA (Becton Dickinson, New Jersey, USA) and sent to the Laboratory of Clinical Pathology of the Veterinary Hospital of the School of Veterinary Medicine and Animal Science of the Federal University of Goiás. Red blood cell, leukocyte and platelet counts were 


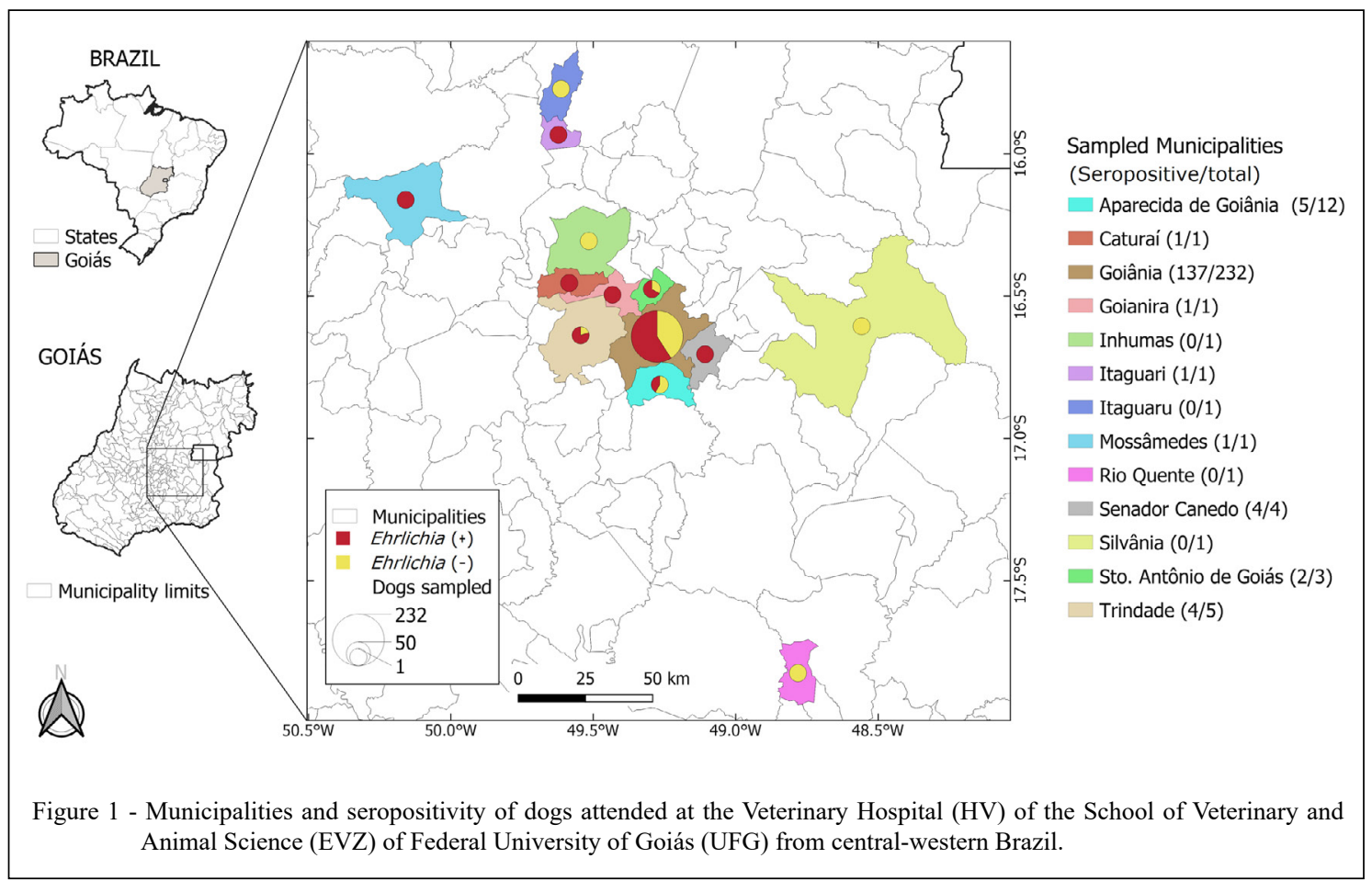

performed using a hematological analyzer (Celltac Alpha/MEK-6550 ${ }^{\circledR}$, Nihon Kohden). Blood smear examination and hematocrit was determined by the microhematocrit method.

The reference values for hematological parameters considered in this study were based on WEISS et al. (2010), as follows: $5.50-8.50 \times 10^{6} / \mu \mathrm{L}$ for red blood cells, 12.0-18.0 g/dL for hemoglobin, $37-55 \%$ for hematocrit, $200-500 \times 10^{3} / \mu \mathrm{L}$ for platelets, and $6,000-17,000 / \mu \mathrm{L}$ for leukocytes.

\section{Indirect immunofluorescence assay (IFA)}

Serum samples were tested by an IFA using crude antigens of $E$. canis (strain Cuiabá \#1), prepared in a cell culture, as previously described (AGUIAR et al., 2007, 2008). Reactions were performed with FITC-labeled anti-dog IgG (SigmaAldrich) previously titrated to the best working dilution $(1: 1000)$, as described elsewhere (RISTIC et al., 1972; AGUIAR et al., 2007). On each slide, a nonreactive and a reactive serum sample (endpoint titer of 1,280 ) were included as negative and positive controls, respectively. Control serum samples derived from studies by AGUIAR et al. (2007) and KRAWCZAK et al. (2012). A serum sample was considered to contain antibodies to $E$. canis if reactive at the 1:40 dilution. Samples reacting at the screening dilution (1:40) were then titrated using serial fourfold dilutions to determine endpoint titers. For comparison purposes, antibody titers were classified as low-medium titer $(<10,240)$ or high titer $(10,240)$.

\section{Statistical analyzis}

The minimal sample size $(n=264)$ was calculated using the software WinEpi (http://www. winepi.net/uk/index.htm), considering a confidence level of $90 \%$, unknown population size, expected proportion of $42 \%$ (based on DUARTE et al., 2013) and margin of error of $5 \%$.

Hematological parameters were compared between three groups of dogs [seronegative, seropositive with low-medium titers $(<10,240)$ and seropositive with high titer $(10,240)]$, using chisquare test or Fisher's exact test, with Bonferroni correction. The association of serological status (negative and positive) with sex, age and breed were also performed with chi-square or Fisher's exact tests. The $95 \%$ confidence interval $(95 \% \mathrm{CI})$ of seroprevalences was also calculated. All statistical analyzes were performed using $\mathrm{R}$ program (version 3.6.1) and a $\mathrm{P}$ $<0.05$ was considered as statistically significant.

The hematological parameters considered in these analyzes were: anemia, leukopenia, leukocytosis, thrombocytopenia, thrombocytosis, 
pancytopenia, anemia plus thrombocytopenia, anemia plus leukocytosis, anemia plus leukopenia, and anemia plus thrombocytopenia plus leukocytosis.

\section{RESULTS}

Overall, $59.1 \%$ of dogs $(156 / 264)$ reacted to E. canis crude antigens (Figure 1). In particular, $51.3 \%$ presented endpoint titers $<10,240$ and $48.7 \%$ had an endpoint titer of 10,240 (the maximum tested herein). Overall, anemia, thrombocytopenia, leukopenia and pancytopenia were detected in $37.1 \%, 29.2 \%$, $10.6 \%$ and $2.3 \%$ of dogs, respectively. Concerning seropositive dogs, anemia, thrombocytopenia, leukopenia and pancytopenia were detected in $44.9 \%$, $39.1 \%, 14.1 \%$ and $3.8 \%$ of dogs (Table 1 ).

Anemia $\left(\mathrm{X}^{2}=9.01, \mathrm{df}=3, \mathrm{p}\right.$-value $=$ $0.0027)$, leukopenia $\left(\mathrm{X}^{2}=4.05, \mathrm{df}=1, \mathrm{p}\right.$-value $=$ $0.0439)$ and thrombocytopenia $\left(\mathrm{X}^{2}=17.06, \mathrm{df}=1\right.$, p-value $<0.001)$ were significantly more frequent in seropositive dogs than in seronegative ones (Table 2). The simultaneous presence of anemia and thrombocytopenia $\left(\mathrm{X}^{2}=12.60, \mathrm{df}=3, \mathrm{p}\right.$-value $\left.<0.001\right)$ was also significantly more frequent in seropositive dogs, as compared to seronegative dogs (Table 2).

By comparing hematological abnormalities between seronegative dogs and seropositive dogs with moderate and high antibody titers, anemia and leukopenia were significantly more frequent in dogs with high antibody titers as compared with seronegative dogs $\left(\mathrm{X}^{2}=11.05, \mathrm{df}=1, \mathrm{p}<0.001\right.$ and $\mathrm{X}^{2}=4.19, \mathrm{df}=1, \mathrm{p}$-value $=0.0404$, respectively). No statistically significant differences were observed for other hematological abnormalities in relation to antibody titers (Table 2).

As far as sex, 59.2\% (90/152) and 58.9\% (66/112) of the females and males, respectively, were positive for antibodies to E. canis. With regard to breed, $60.6 \%(57 / 94)$ and $58.2 \%(99 / 170)$ of mongrels and pure-breed dogs, respectively, were positive. Finally, the seroprevalence varied according to age groups, as follow: $36.8 \%(7 / 19)$ in dogs with $<1$ year, 64\% (48/75) with $1-5$ years, $60 \%(66 / 109)$ with 6-10 years, and 58\% (31/53) with $>10$ years; for eight dogs, age information was missing. Differences in seroprevalence according to sex, breed and age were not statistically significant.

\section{DISCUSSION}

In the present study, we reported a high seroprevalence of $E$. canis in dogs referred to a veterinary teaching hospital in central-western Brazil, confirming our initial hypothesis. The seroprevalence of E. canis in dogs from Brazil varies widely, according to studies conducted in different geographical regions of the country (VIEIRA et al., 2011; KRAWCZAK et al. 2012; GOTTLIEB et al. 2016; FIGUEREDO et al., 2017; DANTASTORRES et al., 2018, 2020). However, some of these

Table 1 - Hematological abnormalities correlated with the frequency of antibodies to Ehrlichia canis in dogs attended at the Veterinary Hospital (HV) of the School of Veterinary and Animal Science (EVZ) of Federal University of Goiás (UFG).

\begin{tabular}{|lccc}
\hline Hematological alterations & $\begin{array}{c}\text { Frequency of dogs with } \\
\text { hematological alterations (\%) }\end{array}$ & $\begin{array}{c}\text { Frequency of dogs with } \\
\text { antibodies to Ehrlichia with } \\
\text { hematological alterations (\%) }\end{array}$ & $\begin{array}{c}\text { Frequency of seronegative } \\
\text { dogs with hematological } \\
\text { alterations }(\%)\end{array}$ \\
\hline Anemia & $98 / 264(37.1)$ & $70 / 156(44.9)$ & $28 / 108(25.9)$ \\
\hline Thrombocytopenia & $77 / 264(29.2)$ & $61 / 156(39.1)$ & $16 / 108(14.8)$ \\
\hline Thrombocytosis & $30 / 264(11.4)$ & $18 / 156(11.5)$ & $12 / 108(11.1)$ \\
\hline Leukopenia & $28 / 264(10.6)$ & $22 / 156(14.1)$ & $6 / 108(5.6)$ \\
\hline Leukocytosis & $48 / 264(18.2)$ & $29 / 156(18.6)$ & $19 / 108(17.6)$ \\
\hline Pancytopenia & $6 / 264(2.3)$ & $6 / 156(3.8)$ & 0 \\
\hline Anemia + thrombocytopenia & $41 / 264(15.5)$ & $35 / 156(22.4)$ & $6 / 108(5.6)$ \\
\hline Anemia + thrombocytosis & $15 / 264(5.7)$ & $11 / 156(7.1)$ & $4 / 108(3.7)$ \\
\hline Anemia + leukopenia & $11 / 264(4.2)$ & $10 / 156(6.4)$ & $1 / 108(0.9)$ \\
\hline Anemia + leukocytosis & $24 / 264(9.1)$ & $18 / 156(11.5)$ & $6 / 108(5.6)$ \\
\hline Thrombocytopenia + leukopenia & $12 / 264(4.5)$ & $10 / 156(6.4)$ & $2 / 108(1.8)$ \\
\hline Thrombocytopenia + leukocytosis & $15 / 264(5.7)$ & $9 / 156(5.8)$ & $6 / 108(5.6)$ \\
\hline Thrombocytosis + leukopenia & $2 / 264(0.8)$ & $1 / 156(0.6)$ & $1 / 108(0.9)$ \\
\hline Thrombocytosis + leukocytosis & $9 / 264(3.4)$ & $8 / 156(5.1)$ & $1 / 108(0.9)$ \\
\hline
\end{tabular}

Ciência Rural, v.52, n.2, 2022. 
Seroprevalence and hematological abnormalities associated with Ehrlichia canis in dogs referred to a veterinary teaching hospital in... 5

Table 2 - Frequency of hematological abnormalities in dogs resulting seronegative, seropositive with low-medium $(<10,240)$ or high antibody titers $(10,240)$ to Ehrlichia canis, at the Veterinary Hospital (HV) of the School of Veterinary and Animal Science (EVZ) of Federal University of Goiás (UFG).

\begin{tabular}{|c|c|c|c|c|c|c|c|c|c|c|c|c|c|}
\hline \multirow[t]{3}{*}{ Hematological alterations } & & \multirow{2}{*}{\multicolumn{2}{|c|}{ Seronegative }} & \multicolumn{8}{|c|}{ Seropositive } & \multicolumn{2}{|c|}{ Total } \\
\hline & & & & \multicolumn{2}{|c|}{$\begin{array}{l}\text { Low-medium } \\
\text { titer }\end{array}$} & \multicolumn{2}{|c|}{ High-titer } & \multicolumn{2}{|c|}{$\begin{array}{l}\text { Low, medium } \\
\text { and high titer }\end{array}$} & \multirow[b]{2}{*}{$X^{2}$} & \multirow[b]{2}{*}{$\mathrm{p}$-value } & \multirow[b]{2}{*}{$n^{0}$} & \multirow[b]{2}{*}{$(\%)$} \\
\hline & & $\mathrm{n}^{\mathrm{o}}$ & $(\%)$ & $\mathrm{n}^{\mathrm{o}}$ & $(\%)$ & $\mathrm{n}^{\mathrm{o}}$ & $(\%)$ & $\mathrm{n}^{\circ}$ & $(\%)$ & & & & \\
\hline \multirow[t]{2}{*}{ Anemia } & Yes & 28 & 25.9 & 31 & 38.8 & 39 & 51.3 & 70 & 44.9 & \multirow[t]{2}{*}{9.01} & \multirow[t]{2}{*}{$0.0027^{*}$} & 98 & 37.1 \\
\hline & No & 80 & 74.1 & 49 & 61.3 & 37 & 48.7 & 86 & 55.1 & & & 166 & 62.9 \\
\hline \multirow[t]{2}{*}{ Leukopenia } & Yes & 6 & 5.6 & 10 & 12.5 & 12 & 15.8 & 22 & 14.1 & \multirow[t]{2}{*}{4.05} & \multirow[t]{2}{*}{$0.0439^{*}$} & 28 & 10.6 \\
\hline & No & 102 & 94.4 & 70 & 87.5 & 64 & 84.2 & 134 & 85.9 & & & 236 & 89.4 \\
\hline \multirow[t]{2}{*}{ Leukocytosis } & Yes & 19 & 17.6 & 15 & 18.8 & 14 & 18.4 & 29 & 18.6 & \multirow[t]{2}{*}{0.001} & \multirow[t]{2}{*}{0.96} & 48 & 18.2 \\
\hline & No & 89 & 82.4 & 65 & 81.3 & 62 & 81.6 & 127 & 81.4 & & & 216 & 81.8 \\
\hline \multirow[t]{2}{*}{ Thrombocytopenia } & Yes & 16 & 14.8 & 27 & 33.8 & 34 & 44.7 & 61 & 39.1 & \multirow[t]{2}{*}{17.06} & \multirow[t]{2}{*}{$<0.001^{*}$} & 77 & 29.2 \\
\hline & No & 92 & 85.2 & 53 & 66.3 & 42 & 55.3 & 95 & 60.9 & & & 187 & 70.8 \\
\hline \multirow[t]{2}{*}{ Thrombocytosis } & Yes & 12 & 11.1 & 12 & 15.0 & 6 & 7.9 & 18 & 11.5 & \multirow[t]{2}{*}{8.42} & \multirow[t]{2}{*}{1} & 30 & 11.4 \\
\hline & No & 96 & 88.9 & 68 & 85.0 & 70 & 92.1 & 138 & 88.5 & & & 234 & 88.6 \\
\hline \multirow[t]{2}{*}{ Pancytopenia } & Yes & 0 & 0.0 & 3 & 3.8 & 3 & 3.9 & 6 & 3.8 & \multirow[t]{2}{*}{1.69} & \multirow[t]{2}{*}{0.100} & 6 & 2.3 \\
\hline & No & 108 & 100.0 & 77 & 96.3 & 73 & 96.1 & 150 & 96.2 & & & 258 & 97.7 \\
\hline \multirow[t]{2}{*}{ Anemia + thrombocytopenia } & Yes & 6 & 5.6 & 19 & 23.8 & 16 & 21.1 & 35 & 22.4 & 12.60 & $<0.001^{*}$ & 41 & 15.5 \\
\hline & No & 102 & 94.4 & 61 & 76.3 & 60 & 78.9 & 121 & 77.6 & & & 223 & 84.5 \\
\hline Anemia + leukocytosis & Yes & 6 & 5.6 & 7 & 8.7 & 11 & 14.5 & 18 & 11.5 & 2.09 & 0.148 & 24 & 9.1 \\
\hline & No & 102 & 94.4 & 73 & 91.3 & 65 & 85.5 & 138 & 88.5 & & & 240 & 90.9 \\
\hline Anemia + leukopenia & Yes & 1 & 0.9 & 5 & 6.3 & 5 & 6.6 & 10 & 6.4 & 3.53 & 0.060 & 11 & 4.2 \\
\hline & No & 107 & 99.1 & 75 & 93.8 & 71 & 93.4 & 146 & 93.6 & & & 253 & 95.8 \\
\hline Anemia + thrombocytopenia & Yes & 2 & 1.8 & 4 & 5.0 & 3 & 4.1 & 7 & 4.5 & 0.664 & 0.414 & 9 & 3.4 \\
\hline + leukocytosis & No & 106 & 98.2 & 76 & 95.0 & 73 & 95.9 & 149 & 95.5 & & & 255 & 96.6 \\
\hline Total & & 108 & & 80 & & 76 & & 156 & & & & 264 & \\
\hline
\end{tabular}

Chi-square and $\mathrm{p}$ value refer to comparison between seronegative and seropositive dogs; ${ }^{*}$ significant difference using chi-square test.

studies have enrolled a limited number of dogs, so data should be interpreted with caution. Moreover, these studies have targeted different dog populations, including hospital-based populations (e.g., BULLA et al., 2004; TRAPP et al., 2006; CARLOS et al., 2007; DINIZ et al., 2007; CARVALHO et al., 2008; NAKAGHI et al., 2008; ORIÁ et al., 2008; BORIN et al., 2009; SANTOS et al., 2009). In hospitalbased studies, the seroprevalence reached as high as $70.1 \%(138 / 198)$ in sick dogs referred to a veterinary teaching hospital in Botucatu, São Paulo, southeast Brazil (DINIZ et al., 2007).

While many studies have been conducted in other Brazilian regions, information on the seroprevalence of E. canis in dogs from Centralwestern Brazil is scarce. Our study is the third largest hospital-based study conducted in Brazil, in terms of sample size. In a study conducted in a veterinary teaching hospital in Londrina, southern Brazil, authors tested 381 dogs using a point-of-care ELISA and 87 (23\%) of them were positive (TRAPP et al., 2006). In another study carried out in a veterinary teaching hospital Santa Maria, southern
Brazil, 316 dogs were evaluated and 14 (4.4\%) were seropositive (KRAWCZAK et al., 2012). Our results showed a much higher seroprevalence (i.e., $59.1 \%$ ), suggesting that even privately-owned dogs that have access to healthcare services in centralwestern Brazil may be highly exposed to E. canis. This indicate that tick control measures to reduce the risk of tick-borne pathogen transmission are not frequently applied or, if applied, not being effective in the studied population.

The high seroprevalence of E. canis in the Central-western Brazil may also be partly explained by the presence of the tropical lineage of $R$. sanguineus s.l. in this region of the country, rather than $R$. sanguineus sensu stricto (=temperate lineage) (NAVA et al., 2018). In fact, an experimental study demonstrated that $R$. sanguineus s.s. ticks from southeastern Brazil, which belong to the tropical lineage, were competent vectors of $E$. canis (MORAES-FILHO et al., 2015). Yet, R. sanguineus s.s. ticks from southern Brazil, Argentina and Uruguay were not (MORAES-FILHO et al., 2015). While further studies with other tick populations and 
E. canis strains are still needed, available data suggest that South American populations of $R$. sanguineus s.s. apparently lacks vector competence for E. canis, while the tropical lineage is highly competent in transmitting this pathogen.

In a previous study conducted in the veterinary teaching hospital investigated herein, authors detected Ehrlichia DNA in 17 (42.5\%) out of 40 sick dogs (DUARTE et al., 2013). These dogs presented variable clinical signs, including fever, pale mucous membranes, inappetence, prostration, occasionally associated to blood coating abnormalities and tick infestation. These findings along with data presented herein indicate that dogs exposed to $E$. canis are more likely to present clinical signs and/or clinicopathological abnormalities.

In this regard, anemia, leukopenia and thrombocytopenia were significantly more frequent in seropositive dogs. Thrombocytopenia in the acute phase may be accompanied by anemia and reduced leukopenia, but in the chronic phase they usually present more marked values (HARRUS \& WANER, 2011), leading to pancytopenia, usually due to bone marrow hypoplasia, a severe sign observed in the chronic phase of CME (HARRUS \& WANER, 2011). In our study, pancytopenia was observed in $3.8 \%(6 / 156)$ of the dogs, but a much higher frequency has been reported elsewhere in a small group of sick dogs (NAKAGHI et al., 2008). These hematological abnormalities have also been reported in previous studies carried out in Brazil (OLIVEIRA et al. 2000; BULLA et al., 2004; MACIEIRA et al., 2005; NAKAGHI et al., 2008; ORIÁ et al 2008; SANTOS et al., 2009; UENO et al. 2009; FONSECA et al., 2017). For instance, the prevalence of $E$. canis in dogs with thrombocytopenia ranged from $26.8 \%$ (30/112) to $45.0 \%(66 / 146)$ (BULLA et al., 2004; MACIEIRA et al., 2005; SANTOS et al., 2009). Nonetheless, while hematological abnormalities such as thrombocytopenia are commonly seen in CME (SAINZ et al., 2015), these are unspecific and may be present in other tick-borne diseases (DE TOMMASI et al., 2013). Thus, while platelet count is a good indicator of CME, thrombocytopenia is not a specific finding and should not be used alone to establish a diagnosis (HARRUS \&WANER, 2011).

It is worth mentioning that the IFA is considered the 'gold standard' test for detecting anti-E. canis IgG antibodies, indicating exposure to E. canis. However, a definitive diagnosis of E. canis infection requires molecular techniques, such as PCR (HARRUS \& WANER, 2011), which is a limitation of the current study.

\section{CONCLUSION}

This study demonstrated that dogs referred to a veterinary teaching hospital in Central-western Brazil are highly exposed to $E$. canis and that seropositive dogs are more likely to present hematological abnormalities, particularly anemia, thrombocytopenia and leukopenia. To our knowledge, this is the first study on detection of anti-E. canis antibodies by means of IFA among dogs in the state of Goiás. Our results highlight the need for increasing awareness among dog owners regarding tick control measures Central-western Brazil, ultimately to reduce the risk of exposure to E. canis and other tickborne pathogens.

\section{DECLARATION OF CONFLICT OF INTEREST}

Authors declare they have no competing interest.

\section{BIOETHICS AND BIOSSECURITY COMMITTEE APPROVAL}

Collection of serum samples from dogs was previously authorized by the Institutional Animal Care and Use Committee (IACUC) of the Universidade Federal de Goiás (protocol 102/17).

\section{ACKNOWLEDGEMENTS}

We thank the Conselho Nacional de Desenvolvimento Científico e Tecnológico (CNPq) for the financial support (project financing and grants) and F. DantasTorres and D.M. Aguiar are also recipients of a research fellowship from $\mathrm{CNPq}$ (respective grants number: 313118/ 2018-3 and $3303677 / 2018-0$ ). This study also was financed (scholarships) in part by the Fundação de Amparo à Pesquisa do Estado de Goiás (FAPEG) and Coordenação de Aperfeiçoamento de Pessoal de Nível Superior-Brazil (CAPES)_Finance Code 001.

\section{AUTHORS' CONTRIBUTIONS}

All authors contributed equally for the conception and writing of the manuscript. All authors critically revised the manuscript and approved of the final version.

\section{REFERENCES}

AGUIAR, D. M. et al. Serological diagnosis of canine monocytic ehrlichiosis with Brazilian antigen of Ehrlichia canis. Ciência Rural, v.37, n.3, p.796-802, mai-jun. 2007. Available from: $<$ https:// www.scielo.br/j/cr/a/7YQwjSV7GzLFGSmQrQwVK8g/?lang=pt>. Accessed: Nov. 01, 2019. doi: 10.1590/S0103-84782007000300030.

AGUIAR, D. M. et al. In vitro isolation and molecular characterization of an Ehrlichia canis strain from São Paulo, Brazil. Brazilian Journal of Microbiology, v.39, n.3, p.489-493, sept. 2008. Available from: <https://www.scielo.br/j/bjm/a/yZzM JsnNGNmZrrdFHQyL4Rb/?lang=en>. Accessed: Aug. 18, 2019. 
doi: $10.1590 / \mathrm{S} 1517-83822008000300014$.

BADER, J., et al. Vector-borne pathogens in dogs from Guatemala, Central America. Veterinary Parasitology, Regional Studies and Reports, v.22, n.1-3, sept. 2020. Available from: <https:// europepmc.org/article/med/33308725>. Accessed: Oct. 06, 2020. doi: $10.1016 /$ j.vprsr.2020.100468.

BORIN, S., et al. Aspectos epidemiológicos, clínicos e hematológicos de 251 cães portadores de mórula de Ehrlichia spp. naturalmente infectados. Arquivo Brasileiro de Medicina Veterinária e Zootecnia, v.61, n.3, p.566-571, jun. 2009. Available from: <https://www.scielo.br/j/abmvz/a/ GgXhDRpvk7cHcpbkscQwQ6B/abstract/?lang=pt $>$. Accessed: Nov. 16, 2019. doi: 10.1590/S0102-09352009000300007.

BULLA, C. et al. The relationship between the degree of thrombocytopenia and infection with Ehrlichia canis in an endemic area. Veterinary Research, v.35, n.1, p.141-146, janfeb. 2004. Available from: <https://www.vetres.org/articles/vetres/ abs/ 2004/01/V4102/V4102.html>. Accessed: Nov. 19, 2019. doi: 10.1051/vetres:2003038.

CARLOS, R. S. et al. Frequency of antibodies anti-Ehrlichia canis, Borrelia burgdorferi and Dirofilaria immitis antigens in dogs from microrregion Ilhéus-Itabuna, State of Bahia, Brazil. Revista Brasileira de Parasitologia Veterinária, v.16, n.3, p.117-120, sept. 2007. Available from: <https://www.scielo.br/j/rbpv/a/ fM8cGmR7xtfjZwcwVmN6JmL/abstract/?lang=en>. Accessed: Sep. 30, 2019. doi: 10.1590/S1984-29612007000300001.

CARVALHO, F. S. et al. Epidemiological and molecular study of Ehrlichia canis in dogs in Bahia, Brazil. Genetics and Molecular Research, v.7, n.3, p.657-662, jul. 2008. Available from: <http:// www.funpecrp.com.br/gmr/year2008/vo17-3/pdf/gmr468.pdf $>$. Accessed: Nov. 16, 2019. doi: 10.4238/vol7-3gmr468.

DANTAS-TORRES, F. et al. Prevalence and incidence of vectorborne pathogens in unprotected dogs in two Brazilian regions. Parasites \& Vectors, v.13, n.195, p.1-7, apr. 2020. Available from: $<$ https://parasitesandvectors.biomedcentral.com/articles/10.1186/ s13071-020-04056-8>. Accessed: Oct. 06, 2020. doi: 10.1186/ s13071-020-04056-8.

DANTAS-TORRES, F.; OTRANTO, D. Dogs, cats, parasites, and humans in Brazil: opening the black box. Parasites \& Vectors, v.7, n.22,p.1-25,jan. 2014. Available from: $<$ https://parasitesandvectors. biomedcentral.com/articles/10.1186/1756-3305-7-22>. Accessed: Oct. 06, 2020. doi: 10.1186/1756-3305-7-22.

DANTAS-TORRES, F. et al. Ehrlichia spp. infection in rural dogs from remote indigenous villages in north-eastern Brazil. Parasites \& Vectors, v.11, n.139, mar. 2018. Available from: $<$ https://parasitesandvectors.biomedcentral.com/articles/10.1186/ s13071-018-2738-3>. Accessed: Oct. 06, 2020. doi: 10.1186/ s13071-018-2738-3.

DE TOMMASI, A. S. et al. Are vector-borne pathogen co-infections complicating the clinical presentation in dogs? Parasites \& Vectors, v.6, n.97, apr. 2013. Available from: <https://parasitesandvectors. biomedcentral.com/articles/10.1186/1756-3305-6-97>. Accessed: Oct. 06, 2020. doi: 10.1186/1756-3305-6-97.

DINIZ, P. P. V. P. et al. Surveillance for zoonotic vectorborne infections using sick dogs from Southeastern Brazil. Vector-Borne and Zoonotic Diseases, v.7, n.4, p.689-697, jan. 2008. Available from: <https:/www.liebertpub.com/
doi/10.1089/vbz.2007.0129?url_ver=Z39.88-2003\&rfr $\mathrm{id}=$ ori $\% 3$ Arid $\% 3$ Acrossref.org\&rfr_dat $=$ cr_pub ++0 pubmed $\&>$. Accessed: Nov. 15, 2019. doi: 10.1089/vbz.2007.0129.

DUARTE, S. C. et al. Diagnóstico molecular de Ehrlichia canis em cães de Goiânia, Brasil. Revista de Patologia Tropical, v.42, n.1, p.30-41, jan.-mar. 2013. Available from: <https://www.revistas. ufg.br/index.php/iptsp/article/view/23591>. Accessed: Aug. 13, 2019. doi: 10.5216/rpt.v42i1.23591.

DUMLER, J. S. et al. Reorganization of genera in the families Rickettsiaceae and Anaplasmataceae in the order Rickettsiales: unification of some species of Ehrlichia with Anaplasma, Cowdria with Ehrlichia and Ehrlichia with Neorickettsia, descriptions of six new species combinations and designation of Ehrlichia equi and "HGE agent" as subjective synonyms of Ehrlichia phagocytophila. International Journal of Systematic and Evolutionary Microbiology, v.51, p.2145-2165, nov. 2001. Available from: <https://www.microbiologyresearch.org/content/ journal/ijsem/10.1099/00207713-51-6-2145\#tab2>. Accessed: Aug. 13, 2019. doi: 10.1099/00207713-51-6-2145.

FIGUEREDO, L. A. et al. Exposure to vector-borne pathogens in privately owned dogs living in different socioeconomic settings in Brazil. Veterinary Parasitology, v.243, p.18-23, aug. 2017. Available from: <https://www.sciencedirect.com/science/article/ abs/pii/S0304401717302212?via\%3Dihub>. Accessed: Oct. 06, 2020. doi: 10.1016/j.vetpar.2017.05.020.

FONSECA, J.P. et al. Hematological parameters and seroprevalence of Ehrlichia canis and Babesia vogeli in dogs. Ciência Animal Brasileira, v.18, p.1-9, 2017. Available from: <https://www. scielo.br/j/cab/a/KJJK8dMG9CCZFZvcSpyBPMM/?lang=en>. Accessed: Nov. 18, 2019. doi: 10.1590/1089-6891v18e-36095.

GOTTLIEB, J. et al. Rangelia vitalii, Babesia spp. and Ehrlichia spp. in dogs in Passo Fundo, state of Rio Grande do Sul, Brazil. Revista Brasileira de Parasitologia Veterinária, v.25, n.2, p.172178, apr-jun. 2016. Available from: <https://www.scielo.br/j/ rbpv/a/Y5hB5BQHMK58WfNBg6JSbjQ/?lang=en>. Accessed: Apr. 16, 2019. doi: 10.1590/S1984-29612016041

HARRUS, S. WANER, T. Diagnosis of canine monocytotropic ehrlichiosis (Ehrlichia canis): An overview. The Veterinary Journal, v.187, p.292-296, mar. 2011. Available from: <https://www.sciencedirect.com/science/article/abs/pii/ S1090023310000353?via\%3Dihub>. Accessed: Apr. 04, 2019. doi: $10.1016 /$ j.tvj1.20 10.02.001.

KRAWCZAK, F. S. et al. Serological survey on Ehrlichia sp. among dogs in the central region of Rio Grande do Sul. Revista Brasileira de Parasitologia Veterinária, v.21, n.4, p.415-417, dec. 2012. Available from: $<$ https://www.scielo.br/j/rbpv/a/FGXZ YRKxBnK3d37WF9yGN3G/?lang=en>. Accessed: Jul. 19, 2019. doi: 10.1590/S1984-29612012005000001.

MACIEIRA, D. B. et al. Prevalence of Ehrlichia canis infection in thrombocytopenic dogs from Rio de Janeiro, Brazil. Veterinary Clinical Pathology, v.34, n.1, p.44-48, mar. 2005. Available from: $\quad<$ https://onlinelibrary.wiley.com/doi/abs/10.1111/j.1939165X.2005.tb00008.x?sid=nlm\%3Apubmed $>$. Accessed: Apr. 16, 2019. doi: 10.1111/j.1939-165x.2005.tb00008.x.

MAGGI, R. G. KRÄMER, F. A review on the occurrence of companion vector-borne diseases in pet animals in Latin America. Veterinary Parasitology, v.12, n.145, p.1-37, mar. 2019. 
Available from: <https://parasitesandvectors.biomedcentral.com/ articles/10.1186/s13071-019-3407-x>. Accessed: Sep. 29, 2020 doi: 10.1186/s13071-019-3407-x.

MORAES-FILHO, J. et al. Genetic analysis of ticks belonging to the Rhipicephalus sanguineus group in Latin America. Acta Tropica, v.117, n.1, p.51-55, jan. 2011. Available from: $<$ https://www.sciencedirect.com/science/article/abs/pii/ S0001706X10002391?via\%3Dihub>. Accessed: Nov. 06, 2020 doi: 10.1016/j.actatropica.2010.09.006.

MORAES-FILHO, J. et al. Comparative evaluation of the vector competence of four South American populations of the Rhipicephalus sanguineus group for the bacterium Ehrlichia canis, the agent of canine monocytic ehrlichiosis. PLOS ONE. v.10, n.9, e0139386, sept. 2015. Available from: <https://journals.plos.org/ plosone/article? id=10.1371/journal.pone.0139386>. Accessed: Apr. 16, 2019. doi: 10.1371/journal.pone.0139386.

NAKAGHI, A. C. H. et al. Canine ehrlichiosis: clinical, hematological, serological and molecular aspects. Ciência Rural v.38, n.3,p.766-770, jun. 2008. Available from: $<$ https://www.scielo. $\mathrm{br} / \mathrm{j} / \mathrm{cr} / \mathrm{a} / 5 \mathrm{FgC} 4 \mathrm{v} 9 \mathrm{dmnN} 5 \mathrm{zPBS} 5 \mathrm{HrqSXh} /$ ?lang=en $>$. Accessed: Sep. 30, 2019. doi: 10.1590/S0103-84782008000300027.

NAVA, S. et al. Rhipicephalus sanguineus (Latreille, 1806) Neotype designation, morphological re-description of all parasitic stages and molecular characterization. Ticks and Tick-borne Diseases, v.9, p.1573-1585, sept. 2018. Available from: <https://www.sciencedirect.com/science/article/abs/pii/ S1877959X18302152?via\%3Dihub>. Accessed: Dec. 10, 2020 doi: $10.1016 /$ j.ttbdis.2018.08.001.

OLIVEIRA, D. et al. Anti-Ehrlichia canis antibodies detection by "dot-ELISA" in naturally infected dogs. Revista Brasileira de Parasitologia Veterinária, v.9, n.1, p.1-5, 2000. Available from: <http://www.ufrrj.br/rbpv/912000/c911 5.pdf >. Accessed: Nov. 15, 2019

ORIÁ, A. P. et al. Ophthalmic, hematologic and serologic findings in dogs with suspected Ehrlichia canis infections. Revista Brasileira de Ciência Veterinária, v.15, n.2, p.94-97, mai-ago. 2008. Available from: <https://www.semanticscholar.org/paper/ Ophthalmic $\% 2 \mathrm{C}$ -
hematologic-and-serologic-findings-in-Ori\%C3\%A1-Neto/35393 22020a6f3d35e6c68232al eeb52f5775c96>. Accessed: Sep. 30, 2019. doi: $10.4322 /$ rbcv.2014.202.

RISTIC, M. et al. Serological diagnosis of tropical canine pancytopenia by indirect immunofluorescence. Infection and Immunity, v.6, n.3, p.226-231, sept. 1972. Available from: $<$ https://iai.asm.org/content/6/3/226.long $>$. Accessed: Nov. 01, 2019. doi: 10.1128/IAI.6.3.226-231.1972.

SAINZ, Á. et al. Guideline for veterinary practitioners on canine ehrlichiosis and anaplasmosis in Europe. Parasites \& Vectors, v.8, n.75, p.1-20, feb. 2015. Available from: $<$ https://parasitesandvectors. biomedcentral.com/articles/10.1186/s13071-015-0649-0>. Accessed: Nov. 18, 2019. doi: 10.1186/s13071-015-0649-0.

SANTOS, F. et al. Molecular evaluation of the incidence of Ehrlichia canis, Anaplasma platys and Babesia spp. in dogs from Ribeirão Preto, Brazil. The Veterinary Journal, v.179, n.1, p.145148, jan. 2009. Available from: $<$ https:/www.sciencedirect.com/ science/article/abs/pii/S1090023307003012?via\%3Dihub>. Accessed: Nov. 16, 2019. doi: 10.1016/j.tvj1.2007.08.017.

TRAPP, S. M. et al. Seroepidemiology of canine babesiosis and ehrlichiosis in a hospital population. Veterinary Parasitology, v.140, p.223-230, sept. 2006. Available from: <https://www.sciencedirect. com/science/article/abs/pii/S0304401706002287?via\%3Dihub>. Accessed: Nov. 16, 2019. doi: 10.1016/j.vetpar.2006.03.030.

UENO, T. E. H. et al. Ehrlichia canis em cães atendidos em hospital veterinário de Botucatu, Estado de São Paulo, Brasil. Revista Brasileira de Parasitologia Veterinária, v.18, n.3, p.5761, sept. 2009. Available from: <https://www.scielo.br/j/rbpv/a/ Rtr7DQbdBxX9VtwVN97w44D/?lang=pt>. Accessed: Nov. 19, 2019. doi:10.4322/rbpv.01803010.

VIEIRA, R. F. C. et al. Ehrlichiosis in Brazil. Revista Brasileira de Parasitologia Veterinária, v.20, n.1, p.1-12, mar. 2011. Available from: <https://www.scielo.br/j/rbpv/a/ZfLTRf69df4Mh ktFVwqv7dy/?lang=en $>$. Accessed: Apr. 04, 2019. doi: 10.1590/ S1984-29612011000100002.

WEISS, D. J.; WARDROP, K. J. Schalm's Veterinary 